\title{
Toward Synthesis-derived Applications of Silver Nanoparticles
}

Angela SPOIALA $\breve{A}^{1,2}$, Denisa FICAI ${ }^{2-4}$, Anton FICAI ${ }^{1,2,4-6}$, Luminita CRACIUN ${ }^{7}$, Aurel Mihail TITU $^{8}$, Ecaterina ANDRONESCU ${ }^{1,2,4-6}$

${ }^{1}$ Department of Science and Engineering of Oxide Materials and Nanomaterials, Faculty of Applied Chemistry and Materials Science, University POLITEHNICA of Bucharest (ficaidenisa@yahoo.ro)

${ }^{2}$ POLITEHNICA University of Bucharest, Faculty of Applied Chemistry and Material Science, National Centre for Micro and Nanomaterials; Spl. Independentei 313, 060042 Bucharest, Romania

${ }^{3}$ POLITEHNICA University of Bucharest, Faculty of Applied Chemistry and Material Science, Department of Inorganic Chemistry, Physical Chemistry and Electrochemistry; Gh Polizu street 1-7, 011061 Bucharest, Romania

${ }^{4}$ POLITEHNICA University of Bucharest, Faculty of Applied Chemistry and Material Science,

National Centre for Food Safety; Spl. Independentei 313, 060042 Bucharest, Romania

${ }^{5}$ POLITEHNICA University of Bucharest, Faculty of Applied Chemistry and Material Science, Department of Science and Engineering of Oxide Materials and Nanomaterials; Gh Polizu street 1-7, 011061 Bucharest, Romania

${ }^{6}$ Academy of Romanian Scientists, Spl. Independentei 54, Bucharest, ROMANIA

${ }^{71}$ Department of Inorganic Chemistry, Physic and Electrochemistry, Faculty of Applied

Chemistry and Materials Science, University POLITEHNICA of Bucharest

8. "Lucian Blaga" University of Sibiu, Faculty of Engineering, Industrial Engineering and

Management Departament, 4 Emil Cioran Street, 550025 Sibiu, Romania; Academy of Romanian Scientists, Spl. Independentei 54, 50085 Bucharest, Romania

\begin{abstract}
This paper aims to review the challenges, toxicity, and routes of synthesis and usage of silver nanoparticles in different medical applications but also highlighting their sustainability from both medical and environmental issues. Regarding their toxicity, it is known that silver nanoparticles can destroy over 650 microorganisms comparing with antibiotics.

Supplementary, will be presented in a comparative manner some conventional synthesis routes (physical and chemical methods) and green synthesis routes using plant extracts. The approach using plant extracts have various advantages comparing with physical, chemical and microbial synthesis methods because there is no need to use chemicals, wasteful purifications
\end{abstract}


and high energy requirements. The main focus in "green nanotechnology" was to use either biological micro-organisms or plant extracts which are an alternative to the classical chemical and physical methods.

An important issue that is discussed in the paper is the potential toxicity of silver nanoparticles that may have on human health or on the environment, which powerfully indicates that, the usage and removal of silver nanoparticles must be carefully examined. Also, it needs to focus our attention on the dismissal of silver nanoparticles into the environment and especially in water systems, fact which suggests that this issue must be fully understood and apply accordingly the law.

Keywords: silver nanoparticles, synthesis derived applications, biomedical applications, toxicity

\section{Introduction}

Nanotechnology is increasingly exploited in science and technology and has become a part of modern technology, which, nowadays, can be considered "a key technology of $21^{\text {st }}$ century" [1]. Nanoscience and nanotechnology involve the synthesis, assembly, manipulation and application of the materials characterized by at least one size in the nanometric range, some of these nanomaterials being found in products available in our daily life. Nanoparticles are small sized materials with sizes ranged between 1 and 100 nanometres and due to their very small size lead to a high surface area, the reactivity increases considerable comparing with the bulk materials and many times even the physical properties are strongly changed. Due to their improved chemical and biological reactivity they may easily interact with cells and microorganisms inducing or enhancing existent properties. Metal and metal oxide nanoparticles are extensively evaluated in medicine, environmental protection, energy, electronics, etc. Silver nanoparticles (Ag NPs) are studied for their applicability in biomedical applications [2, 3] (Figure 1) because of their antibacterial, antifungal, antiviral and anti-inflammatory activity [4, 5]. Also, figure 1 is illustrating some diseases that occur in human body along with the reliable biomedical applications of nanoparticles which could bring a great improvement in human health. Silver nanoparticles have been widely used in diagnosis [6], treatment [3], drug delivery 
$[5,7]$, developing medical devices $[1,8]$, wound dressings $[2,5,9,10]$, medical textiles $[6,8,11$, 12] or contraceptive devices [5] as well.

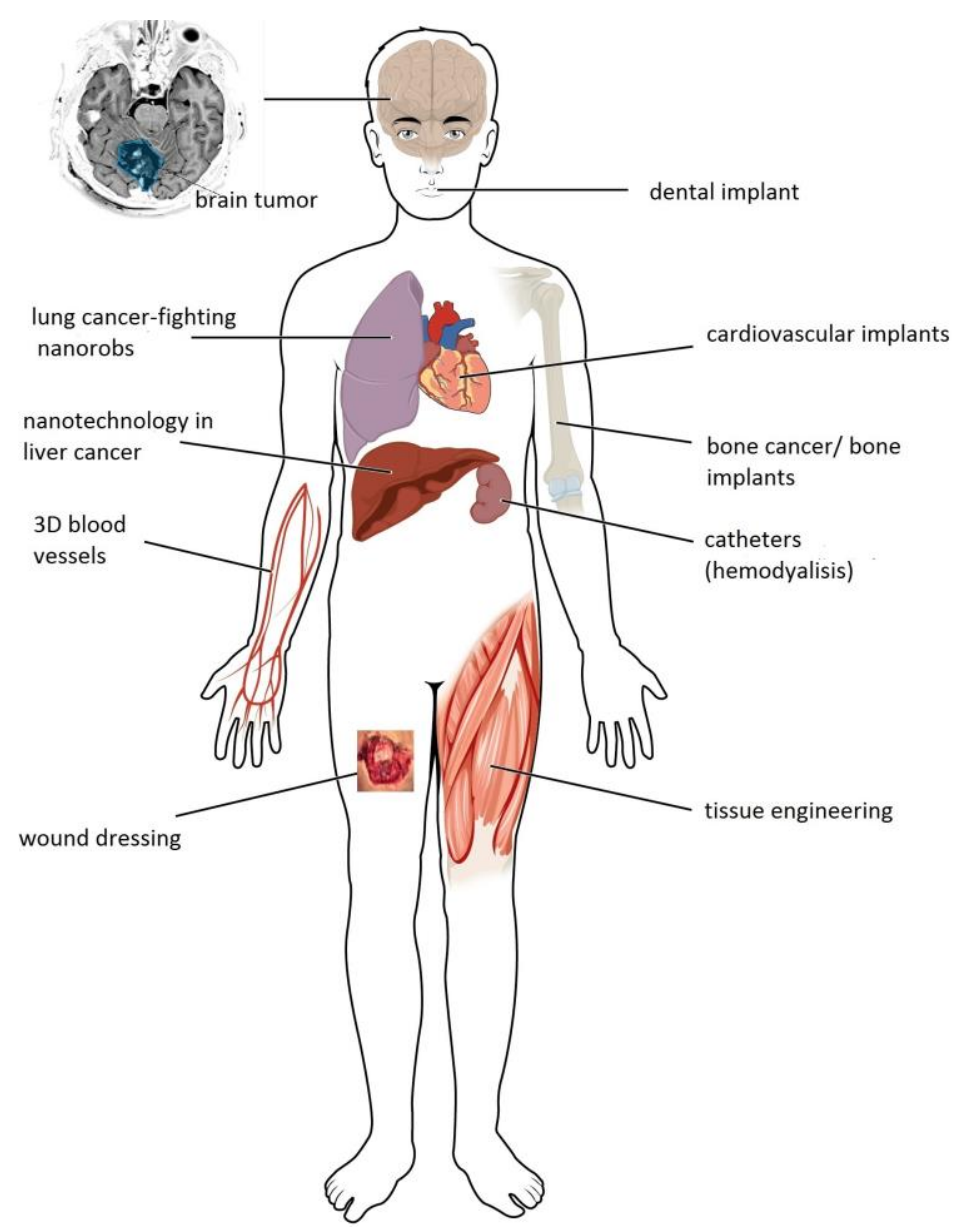

Figure 1. Biomedical applications of Ag NPs - an overview

Based on the recent studies, the necessity to make further investigations and evaluate the toxicity and release of silver in aqueous environmental as well as the release and penetration in contact with skin, have been highlighted as a mandatory step in establishing the opportunity of using these colloids in medical and environmental applications. One of the studies was made on wastewater biofilm which contained planktonic bacteria and due to the antimicrobial effect of silver nanoparticles it can disturb cells and communities' functions and functionalities. For example, the released of $\mathrm{Ag}^{+}$ions and also $\mathrm{Ag}$ NPs can interact with enzymes (usually via the thiol groups), can cause DNA inactivation and could cause a non-culturable state which will conduct to the death of the cells, even in biofilm state $[5,13,14]$. 
When silver nanoparticles or agglomerated particles get into the water systems it must be developed new modalities to overcome the possibility of pollution. Also, the oxidation rate is important because $\mathrm{Ag}^{+}$ions are also biologically active and must be considered when discussing about the overall toxicity. In fact, the speciation of silver in aqueous solution is very complex, silver ion being able to form a wide range of complexes while metallic silver surface can absorb a wide range of molecules. By any meanings, the risk of silver nanoparticles to get into the aqueous systems must be comprehended $[15,16]$. Due to the fact that Ag NPs have antimicrobial application, it also can be useful for water purification $[3,17]$.

Zhang and Chinnapongse [18] have studied the behaviour of silver nanoparticles in different aqueous conditions. They have focused their studies on the transportation of silver nanoparticles in the porous media and on the comprehension of their potential environmental risks. From the current information on silver nanoparticles it is known that $15 \%$ of the total silver that was released into water in the EU came from biocidal plastics and textiles $[19,20]$ so, high environmental risks has to be considered. Moreover, many synthesis protocols involve wet synthesis routes which additionally increase the risks of water contamination.

Since the development of tuneable silver nanoparticles, the silver-based products is constantly growing, it has become a necessity to comprehend its biological interactions and their toxicity [3,5]. This review discusses silver nanoparticles synthesis methods, especially green synthesis from plant extracts, properties, and emerging medical applications [5, 8]. Finally, recent advances concerning the toxicity of silver nanoparticles also are described. It has been already reported that the silver nanoparticles, in small concentration are harmless for human cells but considered biocides against bacteria, fungi and viruses and the only negative effect for human health is skin discoloration $[3,21]$. Products containing silver nanoparticles can be found in pharmaceuticals [9], textiles [6, 11, 12], electronics [8, 22], food packages [22], cosmetics [9] and medical devices $[1,8]$. Because of these issues, it has appeared the need to consider the possibility that may have effects on human health in any possible way [23]. Given its many uses in industry, in medical applications or in water disinfection the silver leakage, long term uptake / bioaccumulation and toxicity should be carefully analysed at both short and long-term [4, 5, 24]. The purpose of this review is to identify the exploitation of silver nanoparticles in medical applications and to examine their effects on the human health and the environment. 


\section{Synthesis routes of silver nanoparticles}

\section{Conventional synthesis routes of silver nanoparticles}

It is well known that some of the processes which concern the synthesis of nanomaterials use toxic substances and involves high amount of energy that can generate potential toxicity. Therefore, the need to create clean, nontoxic and environmentally friendly methods for synthesis of different kind of nanoparticles has been appeared and generally accepted as a necessary precondition [5].

Silver and gold are among the most studied metal nanoparticles due to their potential use in medical treatment; lately, $\mathrm{ZnO}$-NPs have been reported to have non-toxic effect to human cells, due to this aspect appeared the need to use it as antibacterial agent, being lethal to microorganism and having good biocompatibility to human cells [25]. Also, $\mathrm{ZnO}$ can be considered as an environmental friendly antimicrobial agent [26].

Silver nanoparticles, "a wonder of modern medicine" can fight against over 650 microorganisms comparing with the most antibiotics that are active against a much lower number of micro-organisms. Metal nanoparticles have been studied for decades because of their optical [3, 8], electronic [1,8], magnetic [1, 3, 6], antimicrobial [2, 10, 11, 16, 27] and wound healing [5] properties. Due to their multifunctionality, large amounts of metal nanoparticles are needed and for their synthesis multiple methods were proposed and continuously are improved from the point of view of their activity but also synthesis cost, long-term stability, environmental impact, etc [28, 29]. Metal nanoparticles can be prepared by two physical or chemical routes.

The physical route employs processes like evaporation/ condensation and laser ablation. The evaporation/condensation method uses a furnace tube under atmospheric pressure to produce metal nanoparticles. Laser-assisted processing is described by the laser ablation of metals in solution without chemical reagents, which leads to pure silver colloids. As a result, the silver evaporates and is condensed in water, where spherical nanoparticles having 20-30 nm of colloidal silver are obtained, usually in aqueous solution [5]. The characteristics of the metal 
particles formed and the ablation efficiency mainly depend on the wavelength of the laser scattering the metallic target, the duration of the laser pulses, the laser fluency, the ablation time duration and the effective liquid medium [30]. The main factor is that the size of the nanoparticles has been found that increases the laser energy and is generally smallest for fluencies not too far above the laser interruption. As well the laser fluency, the number of laser shots influences the concentration and the morphology of metal particles released in the liquid. Moreover, nanoparticles can be modified in size and shape due to the interaction with the laser light; the development of nanoparticles by laser ablation is influenced by the surfactant shell. The size of the nanoparticles produced in a high surfactant solution is smaller than those produced in a low-content surfactant solution. Thus, there is one benefit in comparison with the conventional method for preparing metal colloids which is the absence of chemical reagents in the solution and the produced pure silver colloids [31].

The other route is the chemical method, where the metal ions in solution are reduced in conditions favouring the subsequent formation of small metal individual particles, clusters or aggregates [31]. Silver nanoparticles can also be synthesized in a two-phase water-organic system. In this process uniform and controllable nanoparticle are produced, with a sharp sizedistribution. The system contains a metal precursor and a reducing agent that are separated into the two phases. The interaction of the precursor /reducing agent occurs controllable, the intensity of interphase transport between the two phases can be controlled and subsequently the reducing process is highly controllable. The surface of the formed silver nanoparticles could be contaminated by the surfactants and organic solvents and the removal of surfactants and organic solvent is mostly time-consuming and expensive [5]. Silver nanoparticles can be prepared by micro-emulsion conditions. The separation of silver nanoparticles in two-phase aqueous organic systems is based on the initial division of reactants in two immiscible phases. The succeeding interaction between the metal precursor and the reducing agent is controlled by the interface between the two liquids. The metal clusters formed at the interface are stabilized, due to their surface coated with capping molecules from the non-polar aqueous medium and transferred to the organic medium by the inter-phase transporter. This method allows preparation of highly uniform and size controllable nanoparticles [31]. 
The preparation of silver nanoparticles through chemical reduction takes place in a stable, colloidal dispersion in water or organic solvents. The most common reduction agents used are borohydride, citrate, ascorbate or in situ generated elemental hydrogen. The reduction of silver ions in aqueous solutions, usually lead to the formation of colloidal silver with particles having several nanometres. So, reducing different complexes of silver ions conducts to the preparation of silver atoms followed by agglomeration into oligomeric clusters which will eventually lead to the formation of colloidal silver particles. Other studies showed that using a stronger reducing agent such as borohydride induces the formation of smaller particles. Also, using a weaker reducing agent such citrate showed a slower reducing rate, but with size distribution far from narrow. For instance, it is highly critical to use protective agents to stabilize dispersive nanoparticles during nanoparticles formation. The most common process is to protect the nanoparticles with agents that can be absorbed or combine on the nanoparticle surface, avoiding their agglomeration. For instance, Olivera et al. [32] adapted dodecanethiol-capped Ag NPs, based on the Brust procedure [33] using dodecanethiol as capping agent of silver nanoparticles which is based on a phase transfer of $\mathrm{Au}^{+3}$ complex from an aqueous to organic solution in a two-phase liquid-liquid system; this procedure is followed by a reduction with sodium borohydride in the presence of dodecanethiol as stabilization agent, avoiding their aggregation and making them dispersible in certain solvents. Through this process, it was showed that changing the synthetic parameters could lead to dramatic modifications in nanoparticle structure, average size and size distribution [31].

\section{Green synthesis of silver nanomaterials}

Green synthesis of silver nanoparticles usually belongs to the chemical route of synthesis and can be separated into five methods: biological methods, polysaccharide method, irradiation method, Tollens methods and polyoxomerales methods. The synthesis of silver nanoparticles in biologic method happens after reduction with microorganism extracts. Preparation of silver nanoparticles using polysaccharides and water as a capping agent is known as polysaccharide method. Sometimes polysaccharides act as both capping and reducing agent. Silver nanoparticles are prepared through various irradiation methods such as formation of silver nanoparticles of various size and shape by laser irradiation of silver salt and proper surfactants. Silver 
nanoparticles can also be fabricated by Tollens methods and polyoxomerale methods. Green synthesis process via the biological route is shown in figure $2[3,34]$.

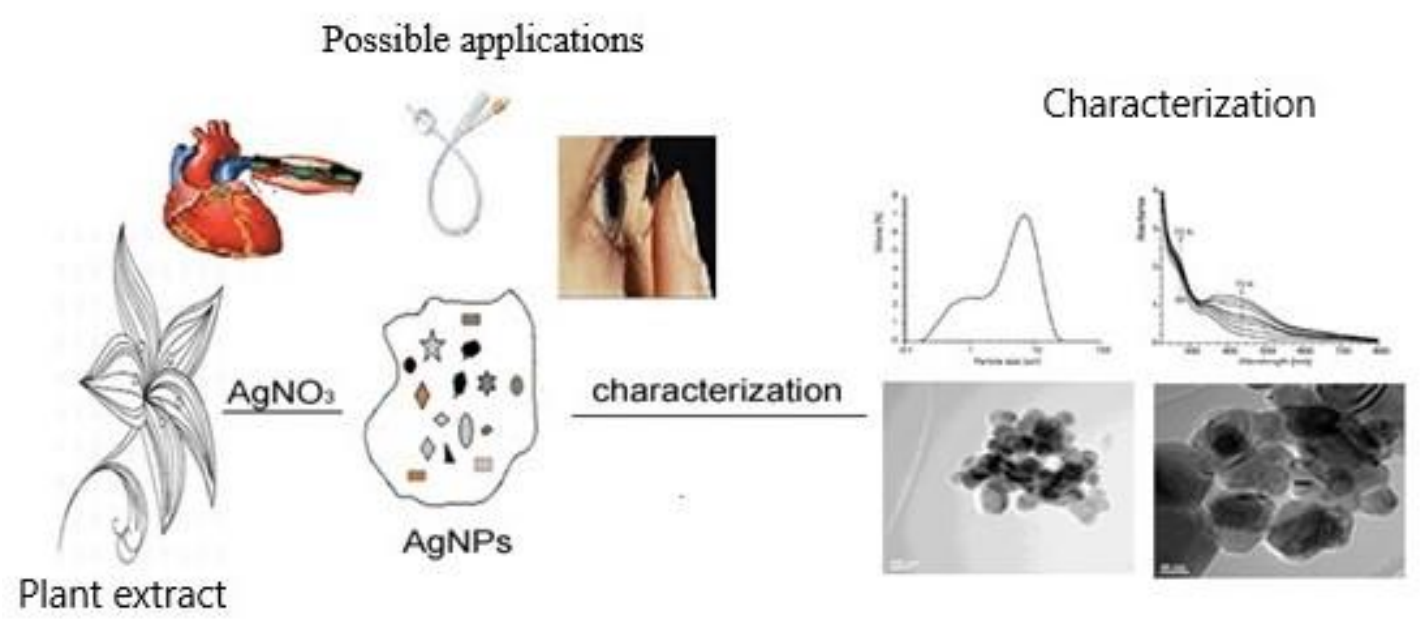

Figure 2. Green synthesis process of silver nanoparticles by using plant extracts

In biosynthesis process, at different concentration of silver nitrate, stable colloidal suspensions with spherical silver nanoparticles with diameter ranging between 0.5 and $150 \mathrm{~nm}$ were produced. Some of the synthesis routes of silver nanoparticles uses plant extract instead of micro-organism due to simplicity, attractiveness, user friendly, economical and fast approach [35]. The approach has various advantages comparing with the physical, chemical and microbial synthesis routes because in this process there is no need to use harmful chemicals, wasteful purifications and high energy requirements. Moreover, the composition of these extracts usually contains both reducing agents as well as capping agents and reduction and stabilisation occurs in one step [22]. By short, green synthesis is an eco-friendly and cost-effective alternative to classical physical and chemical methods. Plants extract are the most conventional reducing agents in green synthesis. Moreover, certain extracts exhibit strong biological activity such as antimicrobial, anti-inflammatory, antitumoral, etc. potentiating the biological activity of the silver colloids as presented in Table 1. Usually, in aqueous solutions silver ions reduces and produces colloidal silver. In crystallization route, Ag ions are reduced to Ag atoms which then grow into oligomeric clusters. Finally these clusters assist in developing the colloidal Ag particles $[3,36]$. 
Table 1. Plant extracts used for silver synthesis and their potential activity.

\begin{tabular}{|c|c|c|}
\hline Plant extracts & Potential activity & Reference \\
\hline $\begin{array}{l}\text { Alternanthera dentate - } \\
\text { leaves extract }\end{array}$ & Antibacterial \& antimicrobial & [37] \\
\hline Acorous calamus - rhizome & Antioxidant, antimicrobial, anticancerous & {$[38]$} \\
\hline $\begin{array}{l}\text { Abutilon indicum - leaves } \\
\text { extract }\end{array}$ & Antibacterial, antimicrobial & {$[39]$} \\
\hline $\begin{array}{l}\text { Cymbopogan citratus - } \\
\text { leaves extract }\end{array}$ & Antibacterial, antimicrobial, antifungal & {$[40]$} \\
\hline Thevetia peruviana - latex & Antimicrobial & {$[41]$} \\
\hline Vitis vinifera - fruit extract & Antimicrobial, antibacterial & {$[42]$} \\
\hline $\begin{array}{l}\text { Musa paradisiacal - peel } \\
\text { extract }\end{array}$ & Antimicrobial & {$[43]$} \\
\hline $\begin{array}{l}\text { Tribulus terrestris }- \text { fruit } \\
\text { extract }\end{array}$ & Antimicrobial & {$[44]$} \\
\hline $\begin{array}{l}\text { Cocous nucifera } \\
\text { inflorescence extract }\end{array}$ & Antibacterial & {$[45]$} \\
\hline $\begin{array}{l}\text { Pistacia atlantica }- \text { seeds } \\
\text { extract }\end{array}$ & Antibacterial & [46] \\
\hline Citrus sinensis - peel extract & Antibacterial & {$[47]$} \\
\hline
\end{tabular}

This "green nanotechnology" has already been using either biological micro-organisms or plant extract which are an alternative to the classical chemical and physical methods [48-50]. 
Many experiments on marine microalgae, fungi and bacteria, Amphora sp, mangosteen extract, aqueous extract of Citrus limon, Coleus aromaticus leaf extract, olive oil extract have been made; in many of these studies the biological materials were used to reduce the silver ions to nanoparticles [51-61]. Nanomaterials may guarantee solutions to medical, technological or environmental issues, but it is strongly recommended that these nanoparticles to be developed through "green" synthesis methods in order to avoid the negative environmental issues. The principles of green chemistry affirm that needs to minimize the use of unsafe products and maximize the efficiency of chemical processes [62].

Since antiquity, it has been highlighted the need to study new effective antimicrobial agents, such silver salts or nanoparticles that has antibacterial effects and could be used for the treatment of the various medical diseases such as mental illness, nicotine addiction, gastroenteritis and infectious diseases like syphilis and gonorrhoea [63-65]. The application fields were drastically extended once with the discovery of their broad activity against the most classes of the hazardous microorganisms. Thus, silver nanoparticles are currently exploited in many applications as presented in Table 2. The following table presents expected applications of silver based active agents and their derived compounds. Some of the important applications include medical applications of silver nanoparticles mainly loaded with different polymers that exhibit low cytotoxicity and hemocompatibility. Table 2 highlights some modified silver nanoparticles with antimicrobial properties with application in medicine and textile industry / antimicrobial clothing but also some other applications that worth mention is presented in this table being related to environmental impact, food safety and energy producing. 


\begin{tabular}{|c|c|c|}
\hline $\begin{array}{l}\text { Crt. } \\
\text { No. }\end{array}$ & Active agents & Expected applications and references \\
\hline \multicolumn{3}{|c|}{ Medical applications } \\
\hline 1 & $\begin{array}{l}\text { Silver nanoparticles (Ag } \\
\left.\mathrm{NP}_{\mathrm{S}}\right) \text { loaded in chitosan/ } \\
\text { gelatine blend }\end{array}$ & $\begin{array}{l}\text { Ag NPs-containing chitosan/gelatine (CS/G) polymers exhibit strong antibacterial activity against } \\
\text { Staphylococcus aureus strains and Escherichia coli strains, limited cytotoxicity, good bond strength with } \\
\text { metal substrate and good biodegradability [66]. It is also important to mention that the initial burst } \\
\text { release of Ag ions prevent the initial adhesion of bacterial strains while exhibiting relatively low } \\
\text { cytotoxicity to healthy cells creating the premises of reduce implant-associated infections. Also, these } \\
\text { formulations can be used in wound dressing, for prevent or even to eradicate infections [67]. }\end{array}$ \\
\hline 2 & $\begin{array}{l}\text { Silver } r \text { nanoparticles } \\
\text { modified } r \text { with } \\
\text { polydopamine and loaded } \\
\text { intorydroxyapatite } \\
(\mathrm{Ag} @ \text { pDA@HAp-NPs) }\end{array}$ & $\begin{array}{l}\text { Silver nanoparticles may induce severe cytotoxicity and limited hemocompatibility when used in } \\
\text { suspension. That is the reason because in most applications the surface of the silver nanoparticles is } \\
\text { modified by adequate capping agents. Silver nanoparticles modified with polydopamine and loaded into } \\
\text { hydroxyapatite was designed for bone tissue engineering, the surface modification of the silver } \\
\text { nanoparticles considerable reducing the cytotoxicity and improving the hemocompatibility while silver } \\
\text { release was of } \sim 80 \% \text { in first day - highlighting good antimicrobial activity against E. coli and S. aureus } \\
\text { followed by a slow release for several days [68]. }\end{array}$ \\
\hline 3 & $\begin{array}{l}\text { Silver loaded magnetic } \\
\text { core@ shell structures } \\
\left(\mathrm{Fe}_{3} \mathrm{O}_{4} @ \mathrm{PTA} @ \mathrm{Ag}\right)\end{array}$ & $\begin{array}{l}\text { Ag nanoparticles (NPs) conjugated onto magnetite nanoparticles through a tannic acid-metal polymer } \\
\text { (PTA) intermediary layer exhibit the bactericidal activity suitable for water disinfection [69]. Similarly, } \\
\text { copper, gold, and silver decorated magnetic core-polymeric shell nanostructures can be designed for } \\
\text { destruction of pathogenic bacteria such as Gram-negative and Gram-positive bacteria [70, 71]. }\end{array}$ \\
\hline
\end{tabular}




\begin{tabular}{|c|c|c|}
\hline 4 & $\begin{array}{l}\text { Silver@carbon } \\
\text { nanocomposites }\end{array}$ & $\begin{array}{l}\text { The multiple-Ag-nanoclustes-C-shell nanocomposites were produced from graft carbon dots (CDs) with } \\
\text { silver nanoparticles (AgNPs). The resulting hollow multiple-Ag-nanoclustes-C-shell nanocomposites } \\
(\mathrm{Ag} @ \mathrm{C}) \text { highlight strong bactericidal effect against both gram-negative and gram-positive bacteria [56], } \\
\text { and limited cytotoxicity against hamster ovarian cells [72, 73]. Another multifunctional material, } \\
\mathrm{Fe}_{3} \mathrm{O}_{4} @ \text { carbon dot } / \mathrm{Ag}\left(\mathrm{Fe}_{3} \mathrm{O}_{4} @ \mathrm{C}-\mathrm{dot} / \mathrm{Ag}\right) \text { nanocubes (NCs) presented catalytic properties [57]. }\end{array}$ \\
\hline 5 & $\begin{array}{l}\text { Silver-coated gold } \\
\text { nanoparticles (Au-Ag NPs) }\end{array}$ & $\begin{array}{l}\text { Ag NPs have antibacterial properties, however Au NPs are biocompatible and easy to prepare, and Au- } \\
\text { Ag NPs were fabricated through } \mathrm{Ag} \text { enhancement, where Au nanoparticles acted as nuclei for } \\
\text { precipitation of Ag forming a core-shell structure immobilized onto a cellulose membrane when treating } \\
\text { with heat. The Au-Ag NPs resulted in having nanoparticles of } \sim 15 \mathrm{~nm} \text { immobilised on cellulose paper } \\
\text { and exhibit excellent antibacterial activity against E. coli JM109 and created the perspectives of using it } \\
\text { as food packaging, clothing, wound dressings, and other personal care products [74]. }\end{array}$ \\
\hline 6 & $\begin{array}{l}\text { Nitroxide-coated silver } \\
\text { nanoparticles (N-Ag NPs) }\end{array}$ & $\begin{array}{l}\text { Nitroxide-coated silver nanoparticles were embedded into the polystyrene by thermoforming at } 140^{\circ} \mathrm{C} \text {. } \\
\text { The antimicrobial activity was proved on Pseudomonas aeruginosa (Gram-negative representative) and } \\
\text { Staphylococcus aureus (Gram-positive representative) as pathogenic bacteria. Polystyrene can be used in } \\
\text { production of packages, including those for food and pharmaceuticals, numerous consumer goods, } \\
\text { housing electronic equipment, inner lining of freezers and refrigerators, foam insulation boards, surgical } \\
\text { instruments, dental tools, dressing materials, prosthesis, etc. In all these applications, the development of } \\
\text { antimicrobial polystyrene is highly recommended while silver nanoparticles are a one of the best choice } \\
\text { in inducing the desired antimicrobial activity [75-81]. }\end{array}$ \\
\hline 7 & $\begin{array}{l}\text { Silver nanostructures } \\
\text { coated with silica Ag } \\
\text { NPs@ } \mathrm{SiO}_{2}\end{array}$ & $\begin{array}{l}\text { Silver nanostructures coated with silica can be obtained by various routes, one presented by Gonzalez- } \\
\text { Castillo et al. [82] involve a three-steps methodology combining assisted laser ablation and redox } \\
\text { reaction, the properties of the core@ shell structures being controlled by laser pulse energy, ablation }\end{array}$ \\
\hline
\end{tabular}




\begin{tabular}{|c|c|c|}
\hline & & $\begin{array}{l}\text { time, concentration of silver and gold salts (and if both silver and gold are used then } \mathrm{Ag}^{+} / \mathrm{Au}^{3+} \text { ratio). } \\
\text { The main advantage of coating silver nanoparticles with porous silica is related to the better stability } \\
\text { while silica shell provides inertness and inequity character which entails possible use in biomedical } \\
\text { applications. }\end{array}$ \\
\hline 8 & $\begin{array}{l}\text { Silica coated with silver } \\
\text { nanostructures }\left(\mathrm{SiO}_{2} @ \mathrm{Ag}\right. \\
\mathrm{NPs})\end{array}$ & $\begin{array}{l}\text { Silica coated with silver nanostructures act as a platform with potential use in nanomedicine, including } \\
\text { cancer treatment. Based on the experimental data provided by Mateis et al. [83], silver release is } \\
\text { promoted by acidic conditions, characteristic to tumour environment, so targeted action can be obtained. } \\
\text { Using these } \mathrm{SiO}_{2} @ \mathrm{Ag} \text { NPs core@ shell structures a combined therapy is assured by the delivery of the } \\
\text { silver ions along with the delivery of bioactive compounds encapsulated into the silica core. These } \\
\text { formulations are of high interest because the mesopores can host a wide variety of biological active } \\
\text { agents inducing new properties or enhancing the existent, antimicrobial activity }[84,85] \text {. }\end{array}$ \\
\hline 9 & $\begin{array}{l}\text { Vancomycin Derivative } \\
\text { Modified Silica-coated } \\
\text { Silver Nanoplate }\end{array}$ & $\begin{array}{l}\text { Complex multi-layered structures based on silica shell coated Ag NPs as nanoplates active cores were } \\
\text { modified with porphyrin-vancomycin (Por-Van) derivative was developed in order to fabricate } \\
\text { AgNPI@ } \mathrm{SiO}_{2} \text {-Por-Van composite to induce Antimicrobial Photodynamic Therapy (aPDT) of } \\
\text { Vancomycin Resistant enterococci bacterial strains (VRE) and, supplementary, able to be used as } \\
\text { imaging agent in Surface-Enhanced Raman Scattering [86]. }\end{array}$ \\
\hline \multicolumn{3}{|c|}{ Antimicrobial clothing } \\
\hline 10 & $\begin{array}{l}\text { Gallic acid modified silver } \\
\text { nanoparticles } \quad \text { GA@Ag } \\
\text { NPs })\end{array}$ & $\begin{array}{l}\text { Antimicrobial leather with durable activity due to the high versatility of linking Gallic acid modified } \\
\text { silver nanoparticles to the surface of the leather [87]. Similarly, tannic acid modified silver nanoparticles } \\
\text { can be obtained and used for antimicrobial purposes [88]. }\end{array}$ \\
\hline 11 & Citrate modified silver & Various textiles were functionalized by silver to induce antimicrobial surfaces. After the \\
\hline
\end{tabular}




\begin{tabular}{|c|c|c|}
\hline & $\begin{array}{l}\text { nanoparticles } \quad \text { (CA@Ag } \\
\text { NPs) }\end{array}$ & 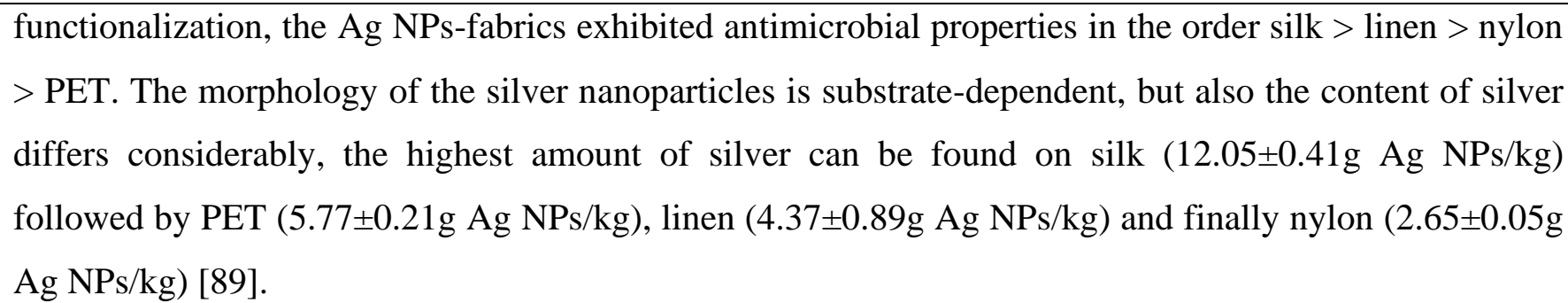 \\
\hline \multicolumn{3}{|c|}{ Energy applications } \\
\hline 12 & $\begin{array}{l}\mathrm{Ag} @ \mathrm{SiO}_{2} \text { nanospheres } \\
\text { deposited onto Indium tin } \\
\text { oxide layer }\end{array}$ & $\begin{array}{l}\mathrm{Ag} @ \mathrm{SiO}_{2} \text { nanospheres were designed to obtain Plasmonic Organic Solar Cells. The optimisation was } \\
\text { done considering the periodicity of the array, the Ag core diameter, the active layer thickness, the shell } \\
\text { thickness, and the refractive index of the shell materials. Based on the study realized by N'Konou et al. } \\
\text { [90] it was found that the optimal periodicity of the } \mathrm{Ag} @ \mathrm{SiO}_{2} \text { array is dependent on the size of } \mathrm{Ag} \text { core. } \\
\text { They found that the use of } \mathrm{Ag} @ \mathrm{SiO}_{2} \text { nanospheres }(50 \mathrm{~nm}) \text { can improve the optical absorption with } \\
24.7 \% \text { (comparing to the similar structure without } \mathrm{Ag} @ \mathrm{SiO}_{2} \text { nanospheres). }\end{array}$ \\
\hline 13 & $\begin{array}{l}\text { Silver nanoparticles and } \\
\text { nanostructured active } \\
\text { materials such as metal } \\
\text { hydroxide, hydrates or } \\
\text { sulphides }\end{array}$ & $\begin{array}{l}\text { Wearable supercapacitors with core@shell hierarchical structure based on silver-coated textile and } \\
\text { nanostructured active materials were obtained using metal hydroxides (e.g. } \mathrm{Ni}(\mathrm{OH})_{2}, \mathrm{Ni}-\mathrm{Co} \text { layered double } \\
\left.\text { hydroxide }(\mathrm{LDH}) \text { ), hydrates (e.g. } \mathrm{NiMoO}_{4} \text { hydrate), and sulphides (e.g. } \mathrm{Ni}(\mathrm{Fe}) \mathrm{Co}_{2} \mathrm{~S}_{4}\right) \text { with three typical } \\
\text { nanostructures of a } 1 \mathrm{D} \text { nanotube array, a } 1 \mathrm{D} \text { nano rod array, and a } 2 \mathrm{D} \text { nano sheet network. As a general } \\
\text { conclusion of the work published by } \mathrm{Li} \text { et al. [91], both the nature of the active materials but also the } \\
\text { morphology is critical factors affecting the performances of the wearable super capacitor. }\end{array}$ \\
\hline \multicolumn{3}{|c|}{ Environmental applications } \\
\hline 14 & $\mathrm{Fe}_{3} \mathrm{O}_{4} @ \mathrm{nSiO}_{2} @ \mathrm{mSiO}_{2} / \mathrm{Pr}-$ & The core@shell nanoparticles with a superparamagnetic iron oxide core $\left(\mathrm{Fe}_{3} \mathrm{O}_{4}\right)$, middle nonporous \\
\hline
\end{tabular}




\begin{tabular}{|c|c|c|}
\hline & $\begin{array}{l}\text { Imi-NH }{ }_{2} \mathrm{Ag} \text { NPs core-shell } \\
\text { microspheres }\end{array}$ & $\begin{array}{l}\text { silica shell }(\mathrm{nSiO}) \text {, and organo functionalized mesoporous silica }\left(\mathrm{mSiO}_{2}\right) \text { were synthesized and } \\
\text { evaluated for retaining } \mathrm{Ag} \mathrm{NPs} \text { onto the nanocomposite. The } \mathrm{Fe}_{3} \mathrm{O}_{4} @ \mathrm{nSiO}_{2} @ \mathrm{mSiO}_{2} \text { was functionalized } \\
\text { with 2-amino ethyl-3 propyl imidazolium bromide resulting magnetic core-shell mesoporous silica } \\
\text { nanoparticles, } \mathrm{Fe}_{3} \mathrm{O}_{4} @ \mathrm{nSiO}_{2} @ \mathrm{mSiO}_{2} / \mathrm{Pr}-\mathrm{Imi}_{-} \mathrm{NH}_{2} \text { and afterwards was embedded with silver } \\
\text { nanoparticles. } \mathrm{Fe}_{3} \mathrm{O}_{4} @ \mathrm{nSiO}_{2} @ \mathrm{mSiO}_{2} / \mathrm{Pr}-\mathrm{Imi}-\mathrm{NH}_{2} \cdot \mathrm{Ag} \mathrm{NPs} \text { core-shell microspheres are highly efficient } \\
\text { catalysts in the aqueous reduction of nitro arenes highlighting improved catalytic activity and facile } \\
\text { catalyst recovery. These systems can be exploited in the environmental protection being able to reduce } \\
\text { aromatic nitro-derivatives to aromatic amino-derivatives with much lower negative environmental } \\
\text { impact [92]. }\end{array}$ \\
\hline 15 & $\begin{array}{l}\mathrm{Fe}_{3} \mathrm{O}_{4} @ \mathrm{SiO}_{2} @ \mathrm{Ag} @ \mathrm{Ni} \\
\text { trepang-like } \\
\text { nanocomposites }\end{array}$ & $\begin{array}{l}\text { The analysis started from } \mathrm{Fe}_{2} \mathrm{O}_{3} \text { nanorods coated with a layer of silica, and after reduction in } 10 \% \mathrm{H}_{2} / \mathrm{Ar} \\
\text { atmosphere, the magnetic } \mathrm{Fe}_{3} \mathrm{O}_{4} \text { was obtained. The } \mathrm{Fe}_{3} \mathrm{O}_{4} @ \mathrm{SiO}_{2} @ \mathrm{Ag} @ \mathrm{Ni} \text { trepang-like nanocomposites } \\
\text { were obtained by coating the } \mathrm{Fe}_{3} \mathrm{O}_{4} \text { nanorods previously obtained with silica followed by final } \\
\text { deposition of } \mathrm{Ag} @ \mathrm{Ni} \text { core } @ \text { shell on the lysine modified surface of } \mathrm{Fe}_{3} \mathrm{O}_{4} @ \mathrm{SiO}_{2} \text {. } \\
\text { It is worth to mention that } \mathrm{Fe}_{3} \mathrm{O}_{4} @ \mathrm{SiO}_{2} @ \mathrm{Ag} @ \mathrm{Ni} \text { trepang-like nanocomposites exhibit remarkable } \\
\text { catalytic efficiency toward the degradation of Rhodamine B at room temperature and this activity is } \\
\text { maintained even after } 6 \text { cycles. Moreover, the magnetic core allow an easy separation / removal of the } \\
\text { catalytic system [93] therefore the negative environmental impact being low. }\end{array}$ \\
\hline 16 & Ag-coated $\mathrm{Fe}_{3} \mathrm{O}_{4} @ \mathrm{TiO}_{2}$ & $\begin{array}{l}\text { The Ag-coated } \mathrm{Fe}_{3} \mathrm{O}_{4} @ \mathrm{TiO}_{2} \text { photocalysts have a core-shell structure formed by } \mathrm{Fe}_{3} \mathrm{O}_{4} \text { core and a nano- } \\
\text { shell of } \mathrm{TiO}_{2} \text { with } \mathrm{Ag} \text { nanoparticles. The Ag-coated } \mathrm{Fe}_{3} \mathrm{O}_{4} @ \mathrm{TiO}_{2} \text { magnetic photocatyst exhibited good } \\
\text { photocatalytic activity in the degradation of Rhodamine } \mathrm{B} \text { under visible light. Chlorophenols are } \\
\text { common pollutants from water which can be destroyed using adequate recyclable and renewable } \\
\text { photocatalyst such as Ag-coated } \mathrm{Fe}_{3} \mathrm{O}_{4} @ \mathrm{TiO}_{2}[94] \text {. }\end{array}$ \\
\hline
\end{tabular}




\begin{tabular}{|c|c|c|}
\hline \multicolumn{3}{|c|}{ Food safety } \\
\hline 17 & $\begin{array}{l}\text { Au@ Ag Core-Shell } \\
\text { Nanoparticles }\end{array}$ & $\begin{array}{l}\text { Food quality and safety are of increasing interest, worldwide. Extensive and many times irrational use of } \\
\text { chemicals (pesticides, insecticides, antibiotics...) lead to food contamination and improved or novel } \\
\text { detection methods should be developed. Au@ Ag Core-Shell Nanoparticles can be used as enhancing agent } \\
\text { to determine amitraz residue in milk because Au@ Ag Core-Shell NPs induce a strong SERS signal at } \\
\mathrm{Au@Ag:} \mathrm{amitraz} \mathrm{ratio} \mathrm{of} 2: 1 \text {. The linearity of Raman intensity (at } 723 \mathrm{~cm}^{-1} \text { ) is in the range of } 9.77 \times 10^{-4} \text { to } \\
2.93 \times 10^{-2} \mathrm{~g} / \mathrm{L} \text {, the recovery of amitraz from milk was found to be between } 81.7 \text { and } 100.5 \% \text { while RSD was } \\
2.61-5.51 \%[95,96] \text {. }\end{array}$ \\
\hline 18 & $\mathrm{Ag} @ \mathrm{SiO}_{2}$ nanoparticles & $\begin{array}{l}\text { The use of enzyme-based miniaturized fluorescence biosensor to detect paraoxon (metabolite of the } \\
\text { insecticide called parathion), one of the most well-known neurotoxic organophosphorus compounds was } \\
\text { developed by Kim et al. [97]. The biosensor was obtained by using PEG as a hydrogel entrapping } \\
\text { acetylcholinesterase and quantum dots as fluorescence reporters. Metal-enhanced fluorescence ( } \mathrm{Ag} @ \mathrm{SiO}_{2} \\
\text { nanoparticles) was used to amplify the fluorescence signal, the signal increase being 5fold comparing with } \\
\text { the system without } \mathrm{Ag} @ \mathrm{SiO}_{2} \text { nanoparticles. The presence of } \mathrm{Ag} @ \mathrm{SiO}_{2} \text { nanoparticles is important because } \\
\text { assure a detection limit of } 1.0 \times 10^{-10} \mathrm{M} \text { (comparing with } 2.0 \times 10^{-7} \mathrm{M} \text { when no } \mathrm{Ag} @ \mathrm{SiO}_{2} \mathrm{NPs} \text { is added). }\end{array}$ \\
\hline
\end{tabular}


The mechanism of action of nanoparticles is very important and differ depending on the nature and characteristics of nanoparticles [11, 13, 31, 98-104]. In the case of silver nanoparticles, the antimicrobial and anti-fungal activity is mainly assured by the produced Reactive Oxygen Species (ROS) which are altering the normal, intracellular functions of these micro-organisms while, most of the metal oxides $(\mathrm{ZnO}, \mathrm{MgO}$ and $\mathrm{CaO})$ are inducing a cellular wall destruction and consequently these microorganisms are losing their integrity. Other metal oxide nanoparticles can induce antimicrobial activity because of the photo-catalytic activity when exposed to visible or UV radiation. Such metal oxides are $\mathrm{TiO}_{2}$ and $\mathrm{ZnO}$. These nanoparticles are effective in aqueous suspension but also many applications are known where these nanoparticles are dispersed into the bulk materials or deposited onto various surfaces [102, 105-107]. The properties can be designed also by developing heterogeneous core@shell structures as 1D (particles), usually dispersed in aqueous suspension or deposited as 2D antimicrobial coating (film) [108, 109].

\section{Advantages and disadvantages of different synthesis routes}

Nanoparticles have multiple applications in aerospace engineering, nano-electronics, environmental remediation, medical healthcare and consumer products and lately silver nanoparticles ranged from disinfecting medical device, water treatment to bio-sensing and imaging applications. Many experiments indicated that different nanoparticles once after inhaled can deposit in the olfactory mucosa of the nasopharyngeal region and can gets to the brain through the olfactory nerve [110]. In vitro studies reported that silver nanoparticles produce toxicity to a variety of organs and leaving cells [111] but it was established that after a 28 day in vivo study, silver doesn't affect neurological or respiratory system [5].

Complex materials based on chitosan-coated with silver nanoparticles showed that exhibit good antimicrobial activity due to the synergic activity of the both antimicrobial agents $[112,113]$. Another application in which hydroxyapatite is doped with silver or loaded with silver nanoparticles in order to obtain antibacterial bone grafts showed promising results being active antibacterial grafting materials against gram-positive ( $S$. aureus) and gram-negative $(E$. coli) bacteria [68]. Silver based materials have also environmental application; for water filtration fibrous materials based on silver nanoparticles and PVA or PAN were obtained and evaluated. Both materials were ideals for water filtration and sanitation and silver hasn't been 
found in water, over the admitted level. From the many applications of silver one of the most significant for human health is related to the detection and treatment of various forms of cancer. Silver loaded hydrogels with curcumin (member of ginger family) exhibit excellent antimicrobial, anti-oxidant, anti-inflammatory and even anti-tumour activity as reported by different research groups [114, 115].

In his article, George J. Maass [116] from Colloidal Science Laboratories and senior scientific advisor at Purest Colloids Inc. reported that "the high biological effectiveness of colloidal silver does not persist in nature because the nanoparticles agglomerate as soon as they come in contact with the species from environment, especially from soil and water" and "once agglomeration occurs, the results is simply silver metal, a harmless metal which has existed in nature from the beginning of our planet" [116]. Unfortunately, these statements are not fully agreed in the scientific literature. Even if the agglomeration leads to the decrease of the toxicity and possibility of internalisation in cells, under different circumstances these agglomerates can break, and their initial toxicity is recovering. Also, the changes of the conditions can lead to a stronger oxidation and thus, the toxicity induced by the higher level of silver ions became important [117, 118].

\section{Toxicity and challenges}

Prime upcoming challenge would be the transition of laboratory use of silver nanoparticles to commercial application, including clinical applications. Researchers and scientists around the world focus their work to study nanoparticles synthesis, their properties and the derived applications. Even at low quantity, the silver nanoparticles could exhibit minor toxicity and could be very dangerous to the organs of the body. To overcome the difficult challenges that come along with the manufacturing of drug delivery systems, diagnosis and treating fatal diseases must be taken into the consideration the possible limitation of silver nanoparticles in some application due to aggregation and potential toxicity. A transition from in vitro to in vivo testing could be the only way to find out the mid- and long-term toxicity. Moreover, the in vivo behaviour can be strongly different comparing to that in vitro where no "in vivo specific mechanisms are available for the organisms". For instance, there are studies on burn patients that cause hypersensitivity, and some are harmful to specific cell lines. It was found that silver nanoparticles can be contaminated (oxidized) in air due to its high surface energy. This 
issue could be overcome by incorporating silver nanoparticles into biodegradable polymer matrix like chitosan, alginate, gelatine, collagen, etc. [119].

Silver nanoparticles may have toxicity over certain concentration and can cause serious health problem. Hence, it is necessary to focus our attention on the safe use of silver nanoparticles for applications involving humans or animals. In vitro, silver nanoparticles have shown cytotoxicity on different types of cells, including human peripheral blood cells, human alveolar epithelial cell, rat liver cell and mouse germ line cells. It has been found that bone cement containing $1 \%$ silver nanoparticles is not leading to cytotoxicity in mouse fibroblasts and human osteoblast cell line. This fact suggests that silver nanoparticles are ionized in the cells producing reactive oxygen species that leads to cell death. In vivo, silver nanoparticles can get into the human body during the exchange materials through the most important portals such as respiratory tract, gastrointestinal tract, skin, and female genital tract. Recent studies related to the silver oral administration to rats, has found that silver nanoparticles accumulates in blood, liver, lungs, kidneys, stomach and brain, but silver nanoparticles showed no genotoxicity after 28 days of oral administration of different doses of silver nanoparticles with size of $60 \mathrm{~nm}$ [5]. At lower size, the shape is also important, and the biological activity is strongly correlated with these factors. The shape, size and charge of the nanoparticles influence proteins that can be absorbed to the nanoparticles surface but if the nanoparticle size is greater than $15-20 \mathrm{~nm}$, it is not considered an important parameter to determine its biological effects. For instance, rod shaped silver nanoparticles in the range of 40-100 $\mathrm{nm}$ presented extraordinary penetration in comparison to spherical and triangular particles. The cell wall penetration and thus the cell internalisation are strongly controlled by size and surface geometry and nature (functionalization agents) [120-122].

This sequence summarizes the molecular procedure of silver nanoparticles toxicity. This procedure explains that toxicity of silver nanoparticles is strictly connected to its transformation in biological and environmental medium and due to surface oxidation; silver ions release and interact with biological macromolecules. It is difficult to define what portion of the toxicity is from the ionic form and what portion is from the metalic-form. Silver NPs can be binded on the membrane proteins and trigger signalling route, which leads to cell proliferation. Ag NPs can also penetrate the cell through diffusion or endocytosis and produce mitochondrial dysfunction, generating reactive oxygen species (ROS) which lead to the damage to the proteins and nucleic 
acids inside the cell and finally the inhibition of cell proliferation. Another important reason for toxicity of Ag NPs is the interaction with both the ionic and metallic forms of the silver with sulphur-containing macromolecules like proteins because of the strong attraction of silver to sulphur [16].

The literature has concluded that silver nanoparticles shown intensive toxic effects upon some tissues and being ingested can induce neurological problems, kidney damage, stomach upset and skin irritation [123-125]. The increasing use of nanomaterials in our life has inevitably caused accumulation in different environments (water, soil and air) and to separate them we need to determinate the aggregation and stability, including tendency of transforming into different species. The approaches presented are necessary to detect the possibilities of the fields of nanotechnology to establish if has any risks for organisms including human beings $[125,126]$. Pure silver nanoparticles were used by Kursungoz et al. [127] to evaluate the neurotoxicity on the rat hippocampal slices. Silver nanoparticles were distributed in the extracellular matrix and were taken inside the cytoplasm of the neutrons. Furthermore, it was found that only larger silver nanoparticles were taken into the neurons via phagocytosis. The silver nanoparticles produced via laser ablation showed that were toxic to the neural tissue [128] showed that neurons affected only the large nanoparticles by phagocytosis, fact that seems to be the main mechanism in silver nanoparticles neurotoxicity.

Another study investigated the potential of $T$. viride (MTCC 5661) to enhance the antimicrobial activity of biosynthesized silver nanoparticles (BSNP) in comparison to citrate stabilized silver nanoparticles (CSNP). Based on the results obtained, BSNP was able to penetrate bacterial membrane more easily than CSNP, which demonstrates the enhancement of antimicrobial efficiency of silver nanoparticles by reducing and modifying their surface with antimicrobial metabolites of cell free filtrate of Trichoderma viride (MTCC 5661) in comparison to citrate stabilized silver nanoparticles. So, this study affirms that biologically synthesized silver nanoparticles coated with antimicrobial metabolites of $T$. viride were more effective than their chemical counterpart in killing of pathogenic bacteria [129].

It is generally accepted that silver nanoparticles, as well as many other engineered nanoparticles alter the human and animal microbiota. This alteration is mostly associated with dysfunctions which are correlated with the size and shape of the silver nanoparticles (AgNC - 
silver nanocubes and AgNS - silver nanospheres) [130-134]. Considering the most representative species of the microbiota it was found that Clostridium spp., Bacteroides uniformis, Christensenellaceae, and Coprococcuseutactus were decreased in AgNC exposed group, whereas, Oscillospira spp., Dehalobacterium spp., Peptococcaeceae, Corynebacterium spp., Aggregatibacterpneumotropica were reduced in AgNS exposed group. The main conclusion of the study is that, even at short-term exposure to AgNS or AgNC, important changes occurs from the point of view of behaviour and viability of the gut microbiota.

\section{Conclusions}

This review focuses on the synthesis methods, especially green synthesis from plant extracts, properties, medical applications, toxicity of silver nanoparticles and the possible impact on the environment. Some of the synthesis routes of silver nanoparticles use plant extracts instead of microorganisms due to simplicity, attractiveness, user friendly, economical issues and their fast approach but also because these extracts can assure, simultaneously, multifunctionality of the silver nanoparticles. The use of proper extracts can assure the necessary reducing agents but also capping agents or additional agents able to induce new biological activities or can enhance existent ones.

Researches affirmed that the synthesis of silver nanoparticles it was found that silver nanoparticles exhibit better antimicrobial activity when adequate natural extracts, metabolites, bacterial lines are chosen and improved internalization was found but, there are only limited papers dealing with this issue so, further confirmations are still necessary, both at short- and long-term level. Based on the statements described it can conclude that silver nanoparticles have an adverse impact on the environment. So, closer attention needs to be paid to the discharge of silver nanoparticles into the environment. Also, silver nanoparticles seem to bio-accumulate, which means that silver nanoparticle concentration will continue to increase over time in water sources. Hence it is strongly suggested that the use and disposal of silver nanoparticles need to be scrutinized. 


\section{Acknowledgement}

The work has been funded by the Operational Programme Human Capital of the Ministry of European Funds through the Financial Agreement 51668/09.07.2019, SMIS code 124705.

\section{References}

[1] Pulit-Prociak J, Banach M. Silver nanoparticles - a material of the future...? Open Chemistry. 2016;14.

[2] Paul DR, Robeson LM. Polymer nanotechnology: Nanocomposites. Polymer. 2008;49:3187-204.

[3] Sheikh Jaber Nurani CKS, Md. Arifur Rahman Khan, Sharif Masnad Hossain Sunny. Silver

Nanoparticles Synthesis, Properties, Applications and Future Perspectives: A Short Review. RJournal of Electrical and Electronics Engineering. 2015;10:117-26.

[4] Are silver nanoparticles safe? Implications for health, the environment and microbial resistance

European Commission- Committee on Emerging and Newly Identified Health Risks (SCENIHR). 2014; 'Nanosilver: safety, health and environmental effects and role in antimicrobial resistance'.

[5] Ge L, Li Q, Wang M, Ouyang J, Li X, Xing MM. Nanosilver particles in medical applications: synthesis, performance, and toxicity. International journal of nanomedicine. 2014;9:2399-407.

[6] Zhang XF, Liu ZG, Shen W, Gurunathan S. Silver Nanoparticles: Synthesis, Characterization, Properties, Applications, and Therapeutic Approaches. International journal of molecular sciences. 2016;17.

[7] Safari J, Zarnegar Z. Advanced drug delivery systems: Nanotechnology of health design A review. Journal of Saudi Chemical Society. 2014;18:85-99.

[8] Natsuki J. A Review of Silver Nanoparticles: Synthesis Methods, Properties and Applications. International Journal of Materials Science and Applications. 2015;4:325.

[9] Kuppusamy P, Yusoff MM, Maniam GP, Govindan N. Biosynthesis of metallic nanoparticles using plant derivatives and their new avenues in pharmacological applications - An updated report. Saudi pharmaceutical journal : SPJ : the official publication of the Saudi Pharmaceutical Society. 2016;24:47384.

[10] Gurunathan S. Rapid biological synthesis of silver nanoparticles and their enhanced antibacterial effects against Escherichia fergusonii and Streptococcus mutans. Arabian Journal of Chemistry. 2014. [11] Khaydarov RR, Khaydarov RA, Estrin Y, Evgrafova S, Scheper T, Endres C, et al. Silver Nanoparticles. 2009:287-97.

[12] Wiemann M, Vennemann A, Blaske F, Sperling M, Karst U. Silver Nanoparticles in the Lung: Toxic Effects and Focal Accumulation of Silver in Remote Organs. Nanomaterials. $2017 ; 7$.

[13] Oktar FN, Yetmez M, Ficai D, Ficai A, Dumitru F, Pica A. Molecular Mechanism and Targets of the Antimicrobial Activity of Metal Nanoparticles. Current Topics in Medicinal Chemistry. 2015;15:1583-8. [14] Morones JR, Elechiguerra JL, Camacho A, Holt K, Kouri JB, Ramirez JT, et al. The bactericidal effect of silver nanoparticles. Nanotechnology. 2005;16:2346-53.

[15] Elzey S, Grassian VH. Agglomeration, isolation and dissolution of commercially manufactured silver nanoparticles in aqueous environments. Journal of Nanoparticle Research. 2009;12:1945-58. [16] McShan D, Ray PC, Yu H. Molecular toxicity mechanism of nanosilver. Journal of food and drug analysis. 2014;22:116-27.

[17] Sheng Z, Liu Y. Effects of silver nanoparticles on wastewater biofilms. Water research. 2011;45:6039-50.

[18] Hu Zhang CZ. Transport of silver nanoparticles capped with different stabilizers in water saturated porous media. J Mater Environ Sci. 2014;5(1):231-6. 
[19] MATHIVANAN. V SA, P. GANESH PRABU, SELVISABHANAYAKAM. Role of Silver Nanoparticles: Behaviour and Effects in the Aquatic Environment - A Review. International Journal of Research in Biological Sciences. 2012;2(2):77082.

[20] Andrady AL. Microplastics in the marine environment. Marine pollution bulletin. 2011;62:1596-605. [21] Li X. FATE OF SILVER NANOPARTICLES IN SURFACE WATER ENVIRONMENTS. The Ohio State University. 2011; Graduate Program in Civil Engineering.

[22] Ahmed S, Ahmad M, Swami BL, Ikram S. A review on plants extract mediated synthesis of silver nanoparticles for antimicrobial applications: A green expertise. J Adv Res. 2016;7:17-28.

[23] Korani M, Ghazizadeh E, Korani S, Hami Z, Mohammadi-Bardbori A. Effects of silver nanoparticles on human health. European Journal of Nanomedicine. 2015;7.

[24] Kaegi R, Voegelin A, Ort C, Sinnet B, Thalmann B, Krismer J, et al. Fate and transformation of silver nanoparticles in urban wastewater systems. Water research. 2013;47:3866-77.

[25] Sirelkhatim A, Mahmud S, Seeni A, Kaus NHM, Ann LC, Bakhori SKM, et al. Review on Zinc Oxide Nanoparticles: Antibacterial Activity and Toxicity Mechanism. Nanomicro Lett. 2015;7:219-42.

[26] Gupta M, Tomar RS, Kaushik S, Mishra RK, Sharma D. Effective Antimicrobial Activity of Green ZnO Nano Particles of Catharanthus roseus. Frontiers in microbiology. 2018;9:2030.

[27] Das B, Dash SK, Mandal D, Ghosh T, Chattopadhyay S, Tripathy S, et al. Green synthesized silver nanoparticles destroy multidrug resistant bacteria via reactive oxygen species mediated membrane damage. Arabian Journal of Chemistry. 2017;10:862-76.

[28] Kulkarni N, Muddapur U. Biosynthesis of Metal Nanoparticles: A Review. Journal of Nanotechnology. 2014;2014:1-8.

[29] Khan I, Saeed K, Khan I. Nanoparticles: Properties, applications and toxicities. Arabian Journal of Chemistry. 2017.

[30] Safila Naveed, Fatima Qamar, Khan M. Synthesis of Silver Nano Particles by Using Chemical Method. American Journal of Chemistry and Applications. 2015;2:pp. 148-50.

[31] Abou El-Nour KMM, Eftaiha Aa, Al-Warthan A, Ammar RAA. Synthesis and applications of silver nanoparticles. Arabian Journal of Chemistry. 2010;3:135-40.

[32] Oliveira MM, Ugarte D, Zanchet D, Zarbin AJ. Influence of synthetic parameters on the size, structure, and stability of dodecanethiol-stabilized silver nanoparticles. J Colloid Interface Sci.

2005;292:429-35.

[33] Mathias Brust CJK. Some recent advances in nanostructure preparation from gold and silver particles - a short topical review. Colloids and SurfacesA: Physicochemical and Engineering Aspects 202 2002:175-86.

[34] Monalisha Rath SSPaNKD. Synthesis of silver nanoparticles from plant extract and its applications for cancer treatment- a review. International Journal of plant, animal and environmental sciences. 2014;4.

[35] T. Sivaranjani AA, P. Thirunavukkarasu, S. Asha. Silver nanoparticle synthesis from plant extracts and its application-a review. International Journal of Advanced Research in Physical Science. 2016;3.

[36] Reidy B, Haase A, Luch A, Dawson KA, Lynch I. Mechanisms of Silver Nanoparticle Release, Transformation and Toxicity: A Critical Review of Current Knowledge and Recommendations for Future Studies and Applications. Materials. 2013;6:2295-350.

[37] Kumar DA, Palanichamy V, Roopan SM. Green synthesis of silver nanoparticles using Alternanthera dentata leaf extract at room temperature and their antimicrobial activity. Spectrochimica acta Part A, Molecular and biomolecular spectroscopy. 2014;127:168-71.

[38] Nakkala JR, Mata R, Gupta AK, Sadras SR. Biological activities of green silver nanoparticles synthesized with Acorous calamus rhizome extract. European journal of medicinal chemistry. 2014;85:784-94.

[39] Ashokkumar S, Ravi S, Kathiravan V, Velmurugan S. Synthesis of silver nanoparticles using A. indicum leaf extract and their antibacterial activity. Spectrochimica acta Part A, Molecular and biomolecular spectroscopy. 2015;134:34-9. 
[40] Shalaka A. Masurkar PRC, Vrishali B. Shidore, Suresh P. Kamble. Rapid Biosynthesis of Silver Nanoparticles Using Cymbopogan Citratus (Lemongrass) and its Antimicrobial Activity. Nano-Micro Lett 3 (3), 189-194. 2011.

[41] Rupiasih NN, Aher A, Gosavi S, Vidyasagar PB. Green synthesis of silver nanoparticles using latex extract of Thevetia peruviana: a novel approach towards poisonous plant utilization. Journal of Physics: Conference Series. 2013;423:012032.

[42] Gnanadhas Gnanajobitha KP, Mahendran Vanaja, Shanmugam Rajeshkumar,, Chelladurai Malarkodi GA, Cellapandian Kannan. Fruit-mediated synthesis of silver nanoparticles using Vitis vinifera and evaluation of their antimicrobial efficacy. Journal Of Nanostructure in Chemistry 2013.

[43] Bankar A, Joshi B, Kumar AR, Zinjarde S. Banana peel extract mediated novel route for the synthesis of silver nanoparticles. Colloids and Surfaces A: Physicochemical and Engineering Aspects. 2010;368:58-63.

[44] Gopinath V, MubarakAli D, Priyadarshini S, Priyadharsshini NM, Thajuddin N, Velusamy P. Biosynthesis of silver nanoparticles from Tribulus terrestris and its antimicrobial activity: a novel biological approach. Colloids and surfaces B, Biointerfaces. 2012;96:69-74.

[45] Mariselvam R, Ranjitsingh AJ, Usha Raja Nanthini A, Kalirajan K, Padmalatha C, Mosae Selvakumar P. Green synthesis of silver nanoparticles from the extract of the inflorescence of Cocos nucifera (Family: Arecaceae) for enhanced antibacterial activity. Spectrochimica acta Part A, Molecular and biomolecular spectroscopy. 2014;129:537-41.

[46] Sadeghi B, Rostami A, Momeni SS. Facile green synthesis of silver nanoparticles using seed aqueous extract of Pistacia atlantica and its antibacterial activity. Spectrochimica acta Part A, Molecular and biomolecular spectroscopy. 2015;134:326-32.

[47] Kaviya S, Santhanalakshmi J, Viswanathan B, Muthumary J, Srinivasan K. Biosynthesis of silver nanoparticles using citrus sinensis peel extract and its antibacterial activity. Spectrochimica acta Part A, Molecular and biomolecular spectroscopy. 2011;79:594-8.

[48] Merin DD, Prakash S, Bhimba BV. Antibacterial screening of silver nanoparticles synthesized by marine micro algae. Asian Pacific Journal of Tropical Medicine. 2010;3:797-9.

[49] Zhang H. Application of Silver Nanoparticles in Drinking Water Purification. "Application of Silver Nanoparticles in Drinking Water Purification". 2013;1-1.

[50] Farias CBB, Silva AF, Rufino RD, Luna JM, Souza JEG, Sarubbo LA. Synthesis of silver nanoparticles using a biosurfactant produced in low-cost medium as stabilizing agent. Electronic Journal of Biotechnology. 2014;17:122-5.

[51] Quester K, Avalos-Borja M, Castro-Longoria E. Biosynthesis and microscopic study of metallic nanoparticles. Micron. 2013;54-55:1-27.

[52] Veerasamy R, Xin TZ, Gunasagaran S, Xiang TFW, Yang EFC, Jeyakumar N, et al. Biosynthesis of silver nanoparticles using mangosteen leaf extract and evaluation of their antimicrobial activities. Journal of Saudi Chemical Society. 2011;15:113-20.

[53] M. Vanaja SR, K. Paulkumar, G. Gnanajobitha, C. Malarkodi and G. Annadurai. Kinetic study on green synthesis of silver nanoparticles using Coleus aromaticus leaf extract. Pelagia Research Library. 2013;4(3):50-5.

[54] Logeswari P, Silambarasan S, Abraham J. Synthesis of silver nanoparticles using plants extract and analysis of their antimicrobial property. Journal of Saudi Chemical Society. 2012.

[55] Jena J, Pradhan N, Dash BP, Panda PK, Mishra BK. Pigment mediated biogenic synthesis of silver nanoparticles using diatom Amphora sp. and its antimicrobial activity. Journal of Saudi Chemical Society. 2014.

[56] Abdel-Aziz MS, Shaheen MS, El-Nekeety AA, Abdel-Wahhab MA. Antioxidant and antibacterial activity of silver nanoparticles biosynthesized using Chenopodium murale leaf extract. Journal of Saudi Chemical Society. 2014;18:356-63.

[57] Muthukrishnan L, Nanda A. Geno-toxic study of silver bio-nanoparticles toward Gram-positive and Gram-negative clinical isolates. Journal of Pharmacy Research. 2013;6:725-9. 
[58] De Jong WH, Van Der Ven LT, Sleijffers A, Park MV, Jansen EH, Van Loveren H, et al. Systemic and immunotoxicity of silver nanoparticles in an intravenous 28 days repeated dose toxicity study in rats. Biomaterials. 2013;34:8333-43.

[59] Vankar PS, Shukla D. Biosynthesis of silver nanoparticles using lemon leaves extract and its application for antimicrobial finish on fabric. Applied Nanoscience. 2011;2:163-8.

[60] Khalil MMH, Ismail EH, El-Baghdady KZ, Mohamed D. Green synthesis of silver nanoparticles using olive leaf extract and its antibacterial activity. Arabian Journal of Chemistry. 2014;7:1131-9.

[61] Logeswari P, Silambarasan S, Abraham J. Synthesis of silver nanoparticles using plants extract and analysis of their antimicrobial property. Journal of Saudi Chemical Society. 2015;19:311-7.

[62] Sharma VK, Yngard RA, Lin Y. Silver nanoparticles: green synthesis and their antimicrobial activities. Advances in colloid and interface science. 2009;145:83-96.

[63] Drake PL, Hazelwood KJ. Exposure-related health effects of silver and silver compounds: a review. Ann Occup Hyg. 2005;49:575-85.

[64] Kim JS, Kuk E, Yu KN, Kim JH, Park SJ, Lee HJ, et al. Antimicrobial effects of silver nanoparticles. Nanomedicine : nanotechnology, biology, and medicine. 2007;3:95-101.

[65] Nagender Reddy Panyala EMP-M, Josef Havel Review: Silver or silver nanoparticles: a hazardous threat to the environment and human health? Journal of APPLIED BIOMEDICINE. 2008;6:117-29. [66] Ma KN, Gong LL, Cai XJ, Huang P, Cai J, Huang D, et al. A green single-step procedure to synthesize Ag-containing nanocomposite coatings with low cytotoxicity and efficient antibacterial properties. International Journal of Nanomedicine. 2017;12:3665-79.

[67] Bin Ahmad M, Lim JJ, Shameli K, Ibrahim NA, Tay MY. Synthesis of silver nanoparticles in chitosan, gelatin and chitosan/gelatin bionanocomposites by a chemical reducing agent and their characterization. Molecules. 2011;16:7237-48.

[68] Chen KL, Xie KN, Long Q, Deng LJ, Fu ZQ, Xiao HH, et al. Fabrication of core-shell Ag@pDA@HAp nanoparticles with the ability for controlled release of Ag+ and superior hemocompatibility. Rsc Advances. 2017;7:29368-77.

[69] Wang T, Ma BB, Jin AW, Li XG, Zhang XL, Wang WJ, et al. Facile loading of Ag nanoparticles onto magnetic microsphere by the aid of a tannic acid Metal polymer layer to synthesize magnetic disinfectant with high antibacterial activity. Journal of Hazardous Materials. 2018;342:392-400.

[70] Padervand M, Karanji AK, Elahifard MR. Copper, gold, and silver decorated magnetic corepolymeric shell nanostructures for destruction of pathogenic bacteria. Russian Journal of Physical Chemistry A. 2017;91:936-45.

[71] Xu GY, Wei XB, Zong CH, Sun YA, Li AX, Ma XJ, et al. A Facile Synthesis of Cu NPs and Ag NPs Coated by PS with Core-Shell Structure by Precipitation Polymerization. Journal of the Chinese Chemical Society. 2017;64:607-11.

[72] Wang KJ, Ji QJ, Li HX, Guan F, Zhang DY, Feng HX, et al. Synthesis and antibacterial activity of silver@carbon nanocomposites. Journal of Inorganic Biochemistry. 2017;166:64-7.

[73] Guo YL, Tang D, Zhang LL, Li B, Iqbal A, Liu WS, et al. Synthesis of ultrathin carbon dots-coated iron oxide nanocubes decorated with silver nanoparticles and their excellent catalytic properties.

Ceramics International. 2017;43:7311-20.

[74] Tsai TT, Huang TH, Chang CJ, Ho NYJ, Tseng YT, Chen CF. Antibacterial cellulose paper made with silver-coated gold nanoparticles. Sci Rep-Uk. 2017;7.

[75] Krystosiak P, Tomaszewski W, Megiel E. High-density polystyrene-grafted silver nanoparticles and their use in the preparation of nanocomposites with antibacterial properties. Journal of Colloid and Interface Science. 2017;498:9-21.

[76] Song J, Chen ML, Regina VR, Wang CX, Meyer RL, Xie EQ, et al. Safe and Effective Ag Nanoparticles Immobilized Antimicrobial NanoNonwovens. Advanced Engineering Materials. 2012;14:B240-B6.

[77] Awad MA, Mekhamer WK, Merghani NM, Hendi AA, Ortashi KMO, Al-Abbas F, et al. Green Synthesis, Characterization, and Antibacterial Activity of Silver/Polystyrene Nanocomposite. Journal of Nanomaterials. 2015. 
[78] Azlin-Hasim S, Cruz-Romero MC, Ghoshal T, Morris MA, Cummins E, Kerry JP. Application of silver nanodots for potential use in antimicrobial packaging applications. Innovative Food Science \& Emerging Technologies. 2015;27:136-43.

[79] Hannon JC, Kerry JP, Cruz-Romero M, Azlin-Hasim S, Morris M, Cummins E. Human exposure assessment of silver and copper migrating from an antimicrobial nanocoated packaging material into an acidic food simulant. Food and Chemical Toxicology. 2016;95:128-36.

[80] Hannon JC, Kerry JP, Cruz-Romero M, Azlin-Hasim S, Morris M, Cummins E. Kinetic desorption models for the release of nanosilver from an experimental nanosilver coating on polystyrene food packaging. Innovative Food Science \& Emerging Technologies. 2017;44:149-58.

[81] Vukoje ID, Vodnik VV, Dzunuzovic JV, Dzunuzovic ES, Marinovic-Cincovic MT, Jeremic K, et al. Characterization of silver/polystyrene nanocomposites prepared by in situ bulk radical polymerization. Materials Research Bulletin. 2014;49:434-9.

[82] Gonzalez-Castillo JR, Rodriguez-Gonzalez E, Jimenez-Villar E, Cesar CL, Andrade-Arvizu JA. Assisted laser ablation: silver/gold nanostructures coated with silica. Appl Nanosci. 2017;7:597-605.

[83] De Matteis V, Rizzello L, Di Bello MP, Rinaldi R. One-step synthesis, toxicity assessment and degradation in tumoral pH environment of SiO2@ Ag core/shell nanoparticles. Journal of Nanoparticle Research. 2017;19.

[84] Qasim M, Singh BR, Naqvi AH, Paik P, Das D. Silver nanoparticles embedded mesoporous SiO(2) nanosphere: an effective anticandidal agent against Candida albicans 077. Nanotechnology.

2015;26:285102.

[85] Liong M, France B, Bradley KA, Zink JI. Antimicrobial Activity of Silver Nanocrystals

Encapsulated in Mesoporous Silica Nanoparticles. Adv Mater. 2009;21:1684-9.

[86] Jiang TT, Wang YF, Liu PL, Tian YX, Li H, Hu YG. Vancomycin Derivative Modified Silica-coated Silver Nanoplate for Surface-enhanced Raman Scattering Imaging and Antimicrobial Photodynamic Therapy of Vancomycin Resistant Bacterial Strains. Chemical Journal of Chinese Universities-Chinese. 2017;38:846-54.

[87] Liu GY, Gao HQ, Li KJ, Xiang J, Lan TX, Zhang ZC. Fabrication of silver nanoparticle sponge leather with durable antibacterial property. Journal of Colloid and Interface Science. 2018;514:338-48. [88] Fang Y, Tan JJ, Lan T, Foo SGF, Pyun DG, Lim S, et al. Universal one-pot, one-step synthesis of core-shell nanocomposites with self-assembled tannic acid shell and their antibacterial and catalytic activities. Journal of Applied Polymer Science. 2018;135.

[89] Emam HE, Rehan M, Mashaly HM, Ahmed HB. Large scaled strategy for natural/synthetic fabrics functionalization via immediate assembly of AgNPs. Dyes and Pigments. 2016;133:173-83.

[90] N'Konou K, Peres L, Torchio P. Optical Absorption Modeling of Plasmonic Organic Solar Cells Embedding Silica-Coated Silver Nanospheres. Plasmonics. 2018;13:297-303.

[91] Li KD, Zhao T, Wang HF, Zhang S, Deng C. From 1D nanotube arrays to 2D nanosheet networks on silver-coated textiles: new insights into the factors determining the performance of a core-shell hierarchical structure for wearable supercapacitors. J Mater Chem A. 2018;6:1561-73. [92] Nasab MJ, Kiasat AR. Multifunctional Fe3O4@nSiO(2)@mSiO(2)/Pr-Imi-NH2 center dot Ag coreshell microspheres as highly efficient catalysts in the aqueous reduction of nitroarenes: improved catalytic activity and facile catalyst recovery. Rsc Advances. 2016;6:41871-7.

[93] Li C, Sun JJ, Chen D, Han GB, Yu SY, Kang SS, et al. Novel Fe3O4@SiO2@Ag@ Ni trepang-like nanocomposites: High-efficiency and magnetic recyclable catalysts for organic dye degradation. Chinese Physics B. 2016;25.

[94] Choi KH, Park SY, Park BJ, Jung JS. Recyclable Ag-coated Fe3O4@TiO2 for efficient photocatalytic oxidation of chlorophenol. Surface \& Coatings Technology. 2017;320:240-5.

[95] SAMWEL-MANTINGH M, TENNEKES H, BUIJS J. Norms for pesticides in water and agricultural products. A critical review. R Adv Food Sci. 2018;1:63-74.

[96] Li P, Teng YJ, Nie YH, Liu WH. SERS Detection of Insecticide Amitraz Residue in Milk Based on Au@ Ag Core-Shell Nanoparticles. Food Anal Method. 2018;11:69-76. 
[97] Kim M, Kwon JE, Lee K, Koh WG. Signal-amplifying nanoparticle/hydrogel hybrid microarray biosensor for metal-enhanced fluorescence detection of organophosphorus compounds. Biofabrication. 2018; 10 .

[98] Gopinath V, Priyadarshini S, Loke MF, Arunkumar J, Marsili E, MubarakAli D, et al. Biogenic synthesis, characterization of antibacterial silver nanoparticles and its cell cytotoxicity. Arabian Journal of Chemistry. 2017;10:1107-17.

[99] Gunalan S, Sivaraj R, Rajendran V. Green synthesized ZnO nanoparticles against bacterial and fungal pathogens. Progress in Natural Science: Materials International. 2012;22:693-700.

[100] Han C, Pelaez M, Likodimos V, Kontos AG, Falaras P, O'Shea K, et al. Innovative visible lightactivated sulfur doped TiO2 films for water treatment. Applied Catalysis B: Environmental. 2011;107:7787.

[101] Luo X, Xu S, Yang Y, Li L, Chen S, Xu A, et al. Insights into the Ecotoxicity of Silver Nanoparticles Transferred from Escherichia coli to Caenorhabditis elegans. Scientific reports. 2016;6:36465.

[102] Nedelcu IA, Ficai A, Sonmez M, Ficai D, Oprea O, Andronescu E. Silver Based Materials for Biomedical Applications. Current Organic Chemistry. 2014;18:173-84.

[103] Oprea O, Andronescu E, Ficai D, Ficai A, Oktar FN, Yetmez M. ZnO Applications and Challenges. Current Organic Chemistry. 2014;18:192-203.

[104] Ficai D, Oprea O, Ficai A, Holban AM. Metal Oxide Nanoparticles: Potential Uses in Biomedical Applications. Curr Proteomics. 2014;11:139-49.

[105] Pica A, Pica M, Ficai D, Ficai A, Florica D. Incorporation of Silver Nanoparticles in Film Forming Materials for Long Term Antimicrobial Action. Current Nanoscience. 2015;11:760-9.

[106] Ficai D, Sandulescu M, Ficai A, Andronescu E, Yetmez M, Agrali OB, et al. Drug Delivery Systems for Dental Applications. Current Organic Chemistry. 2017;21:64-73.

[107] Mihaiescu DE, Grumezescu AM, Andronescu E, Voicu G, Ficai A, Vasile OR, et al. Prosthetic Devices with Functionalized Anti-biofilm Surface Based NanoAg@C18. Current Organic Chemistry. 2013;17:105-12.

[108] SPOIALA A, ALBU MG, FICAI A, ANDRONESCU E, VOICU G, UNGUREANU C. THE $\mathrm{SiO} / \mathrm{ZnO}$ COMPOSITE MATERIALS FOR COSMETIC CREAMS. Digest Journal of Nanomaterials and Biostructures. 2014;9:1729-37.

[109] Spoiala A, Nedelcu IA, Ficai D, Ficai A, Andronescu E. Zinc Based Antibacterial Formulations for Cosmetic Applications. Digest Journal of Nanomaterials and Biostructures. 2013;8:1235-42.

[110] Patchin ES, Anderson DS, Silva RM, Uyeminami DL, Scott GM, Guo T, et al. Size-Dependent Deposition, Translocation, and Microglial Activation of Inhaled Silver Nanoparticles in the Rodent Nose and Brain. Environ Health Perspect. 2016;124:1870-5.

[111] Ahamed M, Alsalhi MS, Siddiqui MK. Silver nanoparticle applications and human health. Clinica chimica acta; international journal of clinical chemistry. 2010;411:1841-8.

[112] Wang LS, Wang CY, Yang CH, Hsieh CL, Chen SY, Shen CY, et al. Synthesis and anti-fungal effect of silver nanoparticles-chitosan composite particles. International journal of nanomedicine.

2015; 10:2685-96.

[113] Radulescu M, Ficai D, Oprea O, Ficai A, Andronescu E, Holban AM. Antimicrobial Chitosan based Formulations with Impact on Different Biomedical Applications. Current Pharmaceutical Biotechnology. 2015;16:128-36.

[114] Ioan-Avram Nedelcu AF, Maria Sonmez, Denisa Ficai, Ovidiu Oprea and Ecaterina Andronescu. Silver Based Materials for Biomedical Applications. Current Organic Chemistry. 2014;18(2).

[115] Rai M, Yadav A, Gade A. Silver nanoparticles as a new generation of antimicrobials. Biotechnology advances. 2009;27:76-83.

[116] George J. Maass PDCSL. Silver Nanoparticles: No Threat to the Environment. Purest Colloids, Inc. 2008. 
[117] Ray PC, Yu H, Fu PP. Toxicity and environmental risks of nanomaterials: challenges and future needs. Journal of environmental science and health Part C, Environmental carcinogenesis \& ecotoxicology reviews. 2009;27:1-35.

[118] Caballero-Díaz E, Pfeiffer C, Kastl L, Rivera-Gil P, Simonet B, Valcárcel M, et al. The Toxicity of Silver Nanoparticles Depends on Their Uptake by Cells and Thus on Their Surface Chemistry. Part Part Syst Char. 2013;30:1079-85.

[119] Sheikh Jaber Nurani CKS, Md. Arifur Rahman Khan, Sharif Masnad Hossain Sunny. Silver Nanoparticles Synthesis, Properties, Applications and Future Perspectives: A Short Review. Journal of Electrical and Electronics Engineering. 2015;10:117-26.

[120] Ispanixtlahuatl-Meraz O, Schins RPF, Chirino YI. Cell type specific cytoskeleton disruption induced by engineered nanoparticles. Environ-Sci Nano. 2018;5:228-45.

[121] Sun FF, Oh S, Kim J, Kato T, Kim HJ, Lee J, et al. Enhanced Internalization of Macromolecular Drugs into Mycobacterium smegmatis with the Assistance of Silver Nanoparticles. Journal of Microbiology and Biotechnology. 2017;27:1483-90.

[122] Soni N, Jyoti K, Jain UK, Katyal A, Chandra R, Madan J. Noscapinoids bearing silver nanocrystals augmented drug delivery, cytotoxicity, apoptosis and cellular uptake in B16F1, mouse melanoma skin cancer cells. Biomedicine \& Pharmacotherapy. 2017;90:906-13.

[123] S. BP. Review Paper: SILVER OR SILVER NANOPARTICLE A SAFETY OR A RISK. Journal of Environmental Research And Development. 2012;7(1A):452-6.

[124] Marianne Matzke KJ, Thomas Backhaus. Toxicity of differently sized and coated silver nanoparticles to the bacterium Pseudomonas putida: risks for the aquatic environment? PeerJ PrePrints. 2014.

[125] Christina Greulich DB, Alexander Peetsch, Jorg Diendorf, Bettina Siebers, Matthias Epple, Manfred Koller. The toxic effect of silver ions and silver nanoparticles towards bacteria and human cells occurs in the same concentration range. RCS Advances. 2012;2:6981-7.

[126] Yao D, Chen Z, Zhao K, Yang Q, Zhang W. Limitation and Challenge Faced to the Researches on Environmental Risk of Nanotechnology. Procedia Environmental Sciences. 2013;18:149-56.

[127] Kursungoz C, Tas ST, Sargon MF, Sara Y, Ortac B. Toxicity of internalized laser generated pure silver nanoparticles to the isolated rat hippocampus cells. Toxicology and Industrial Health. 2017;33:55563.

[128] Repar N, Li H, Aguilar JS, Li QQ, Drobne D, Hong Y. Silver nanoparticles induce neurotoxicity in a human embryonic stem cell-derived neuron and astrocyte network. Nanotoxicology. 2018;12:104-16. [129] Kumari M, Shukla S, Pandey S, Giri VP, Bhatia A, Tripathi T, et al. Enhanced Cellular Internalization: A Bactericidal Mechanism More Relative to Biogenic Nanoparticles than Chemical Counterparts. Acs Applied Materials \& Interfaces. 2017;9:4519-33.

[130] Jin YX, Wu SS, Zeng ZY, Fu ZW. Effects of environmental pollutants on gut microbiota.

Environmental Pollution. 2017;222:1-9.

[131] Javurek AB, Suresh D, Spollen WG, Hart ML, Hansen SA, Ellersieck MR, et al. Gut Dysbiosis and Neurobehavioral Alterations in Rats Exposed to Silver Nanoparticles. Scientific Reports. 2017;7.

[132] van den Brule S, Ambroise J, Lecloux H, Levard C, Soulas R, De Temmerman PJ, et al. Dietary silver nanoparticles can disturb the gut microbiota in mice. Particle and Fibre Toxicology. 2016;13.

[133] Pietroiusti A, Magrini A, Campagnolo L. New frontiers in nanotoxicology: Gut microbiota/microbiome-mediated effects of engineered nanomaterials. Toxicol Appl Pharm. 2016;299:905.

[134] Williams K, Milner J, Boudreau MD, Gokulan K, Cerniglia CE, Khare S. Effects of subchronic exposure of silver nanoparticles on intestinal microbiota and gut-associated immune responses in the ileum of Sprague-Dawley rats. Nanotoxicology. 2015;9:279-89. 